\title{
Mergers and capital flight in unionised oligopolies: is there scope for a "national champion" policy?
}

\author{
Kjell Erik Lommerud \\ Department of Economics, University of Bergen, Norway \\ Frode Meland \\ Department of Economics, University of Bergen, Norway
}

Odd Rune Straume*

NIPE, University of Minho, Portugal

\begin{abstract}
Many policy makers seem to prefer domestic alternatives to cross-border mergers. We construct a model where cross-border mergers drive down union-set wages, domestic mergers have non-labour cost synergies and policy evaluators care more about workers than capital owners. Apparently, the stage is set for "national champion" policies to be sensible. However, we also introduce the possibility of capital flight by allowing a domestic firm to move production abroad. Restrictive cross-border merger policies can then seriously backfire, since they do not necessarily bring about a domestic merger - but capital flight instead.
\end{abstract}

Keywords: Cross-border merger, national champions, greenfield FDI, trade unions JEL classification: F16, F21, J51, L13

\footnotetext{
* Corresponding author. Address: Department of Economics, University of Minho, Campus de Gualtar, 4710-057 Braga, Portugal. Tel: +351-253601384. Fax: +351-253601380. E-mail:

o.r.straume@eeg.uminho.pt
} 


\section{Introduction}

As firms grow larger and larger, mergers increasingly tend to be international. ${ }^{1}$ At the same time, many observers pose the question if a foreign takeover will lead to changes in decision making in the firm in a way that may hurt domestic stakeholders. If an industry needs restructuring and larger units, would it not be better with national merger alternatives that can help create "national champions" that in turn can play a role on the world arena? Controversial recently proposed cross-border mergers include the attempt by Italian Enel to take over the French electricity and gas firm Suez (where French authorities favoured a merger between Suez and Gaz de France), the proposed takeover of Spanish Endesa by German E.on (where what the European commission called "economic patriotism" from Spanish authorities in the end lead E.on to withdraw its bid) ${ }^{2}$, and the case of Dubai Ports, that sought to take over six major ports on the eastern seaboard of the US. Moreover, in the summer of 2007, Norwegian authorities bought a large share of the oil service firm Aker Kvaerner, in order to

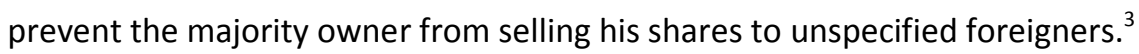

It is sometimes hard to pinpoint exactly what the opponents of ownership globalisation fear. Some seem to worry that international firms will be slightly too profit oriented - so that good jobs and headquarter services will disappear from the national economy - even when the domestic cost disadvantage possibly is quite small. ${ }^{4}$ Others seem to fear that foreign owners

\footnotetext{
${ }^{1}$ See UNCTAD (2005) for documentation on the multinational nature of production and investment.

${ }^{2}$ Endesa was then taken over jointly by Italian firm Enel and Spanish firm Acciona, but this proved an unhappy state of affairs, leading Enel to buy out Acciona in February 2009.

${ }^{3}$ When Aker Kvaerner was formed through a big merger some years earlier, this alternative appeared to be much preferred in Norway to the other alternative, namely a takeover of Kvaerner by Russian Yukos.

${ }^{4}$ Mugele and Schnitzer (2008) explore a theoretical model of the relationship between ownership structure and location decision. Cultural proximity may lead an owner to locate activities at a location
} 
perhaps are too little profit oriented. Vast amounts of money accumulate in oil-rich countries and in new industrial giants as China. The trend is that this money increasingly is placed in sovereign wealth funds. Especially in the US many seem to worry that the commanding heights of the economy might be taken over by foreign parties that possibly have strategic interests that do not coincide with those of the host country. ${ }^{5}$

This paper is an attempt to understand such merger patriotism sentiments, and to discuss if national champion policies in some circumstances can be warranted. More specifically we want to develop a story where cross-border mergers have the potential to harm the interests of domestic workers. The model assumptions are not necessarily chosen for their empirical relevance, but rather to give the national champion argument a fair chance. We consequently open up the possibility that cross-border mergers are driven by the wish to keep down wages for workers in the domestic country. At the same time, we assume that merger synergies are largest in connection with a domestic merger (as opposed to a cross-border alternative). Finally, we assume that policy makers put a higher weight on domestic wage levels than on profits accruing to domestic citizens.

All this would seem to suggest that a national champion policy could be the welfare optimal outcome. Disregarding the relatively few cases where an even more restrictive merger policy (blocking all types of mergers) is nonetheless optimal, this turns out to be correct if a domestic where he or she understands the culture better, so who is the low-cost provider of a service may be dependent on the nationality of the owner.

${ }^{5}$ Economist and previous US finance minister Lawrence Summers aired such scepticism against sovereign wealth funds at the 2008 World Economic Forum meeting in Davos. Kristin Halvorsen, then Norwegian Minister of Finance and thereby representing one of the world's largest sovereign wealth funds, replied, in quite undiplomatic language, that the US "is in deep shit" and relies on the capital inflow from this kind of funds (NTB, 21.01.2008). 
firm only has the choice between merging domestically or internationally. However, we then open up a third possibility. Fixing attention on one particular domestic firm, we assume that this firm has three options when it comes to industrial structure: it can merge domestically or internationally, or it can build up greenfield production capacity abroad and relocate production to a foreign (low-cost) country. ${ }^{6}$

An international merger can be bad from the viewpoint of unionised workers, as their wages are kept down, but full capital flight is even worse, since all jobs in the firm are then lost. Indeed, from the domestic society's viewpoint this kind of capital flight turns out to be the worst of all possible outcomes. A national champion policy that bans cross-border mergers could then just as well lead to the domestic firm investing greenfield abroad and thus fleeing the domestic economy - and not to a domestic merger. This is also what we find as an equilibrium outcome for a sizeable set of parameter values in our model. When a feasible option of capital flight is introduced, the scope for a national champion policy is significantly reduced. If national champion policies (or even more restrictive merger policies) are to make sense even with capital flight as a possibility, this requires a combination of three different industry characteristics: (i) sufficiently high levels of relocation costs, (ii) intermediate levels of domestic merger synergies, and (iii) a sufficiently low degree of product differentiation.

In sum, this paper cautions that a national champion policy can seriously backfire - even in a model setting that on the surface is constructed to make merger patriotism sensible. This does in no way imply that unionised workers cannot be hurt by globalisation or that cross-border mergers cannot be detrimental for domestic welfare, it only means that a restrictive policy towards cross-border mergers is simply not the right policy prescription.

\footnotetext{
${ }^{6}$ It is quite rare in the literature that all these three options are considered within a unified framework. Our model can be seen in the spirit of Grossman, Helpman and Szeidl (2006), who also emphasize that the strategic choice set of multinational firms can be quite broad.
} 
There exists a quite large theoretical economics literature on international mergers, and a substantially smaller body of work on the national champion issue. ${ }^{7}$ The current paper utilises elements that can also be found in Lommerud, Straume and Sørgard (2006). In that paper, cross-border mergers lead to a situation where a multinational firm can play unionised workers in different countries out against each other. This in turn may imply that cross-border mergers take place that are not welfare-improving. Rather, the point of the merger is to tilt the distribution of resources between groups in society, not to maximise surplus in society in some sense. However, that model is set up in such a way that first best merger policy often turns out to be to ban all mergers, rather than to pursue a national champion policy. In the current model, we have tilted the analysis even further in favour of national champions, for example by assuming that only domestic mergers entail variable cost synergies. The essential difference between the two papers, though, is that we here allow the possibility of internationalisation of the firm through foreign direct investment. ${ }^{9}$

Norbäck and Persson (2007) is an interesting paper that concerns itself with investment liberalisation and cross-border mergers, but not the national champion question itself. The authors warn that a restrictive policy towards foreign takeovers can have unwanted effects, but their line of argument is distinctly different from ours. They consider inward greenfield FDI as the alternative to a cross-border merger, but here a domestic national champion merger is

\footnotetext{
${ }^{7}$ Open economy merger policy issues in a wider context are studied, for example, by Barros and Cabral (1994), Head and Ries (1997), Horn and Persson (2001a), Bjorvatn (2004), and Neary (2007).

${ }^{8}$ It is also relevant to mention the large literature on how different groups of workers, perhaps organised in trade unions, fare in the face of globalisation. See for example Naylor (1998), Neary (2002), Meland (2002), Lommerud, Meland and Sørgard (2003), Straume (2003), Saint-Paul (2007), Wälde and Weiss (2007) and Egger and Kreickemeier (2008).

${ }^{9}$ Mukherjee and Zhao (2009) are concerned with how trade unionism shapes the corporate structure of firms, with emphasis on how centralised or decentralised the bargaining system is.
} 
ignored as an alternative. ${ }^{10}$ Norbäck and Persson emphasise that a developing country can harm itself by pursuing a restrictive cross-border merger policy. Combining the strong firmspecific assets of a multinational with the strong country-specific assets of a domestic firm has the potential to create a large surplus. The important point is to create competition for the acquisition of the domestic asset, so that the successful multinational bidder does not pay a too low price. The multinational is not only willing to pay according to what the assets at play are worth by itself, but it also has a value to prevent its competitors from obtaining the domestic firm. ${ }^{11}$

There are several recent papers that discuss the national champion question more directly, but here greenfield FDI is typically not an option. We have learnt from the strategic trade literature that, in an international Cournot oligopoly, policy that increases the market share of domestic producers will be beneficial for the domestic country - if a policy evaluator only cares about the welfare of domestic agents. In such a setting, several papers have investigated whether a national champion type of merger policy can increase the welfare of domestic and foreign agents, and how merger policy interacts with tax policy. Research that broadly pursues his type of questions include Haufler and Nielsen (2008), Haufler and Schulte (2007), Südekum (2008, 2010) and Lommerud, Olsen and Straume (2010). ${ }^{12}$ Note that this type of analysis is quite different from the present model: we focus on how national champion policy can tilt the power balance between domestic stakeholders, which this literature pays little attention to.

\footnotetext{
${ }^{10}$ This also applies for Nocke and Yeaple (2007).

${ }^{11}$ Neary (2009) studies cross-border mergers and greenfield market entry in a trade liberalisation perspective. Raff, Ryan and Schäfer (2009) envisage three different foreign market entry modes: mergers and greenfield entry, but also joint ventures. Calmette (2008) models merger formation and trade liberalisation in a North-South context.

${ }^{12}$ Huck and Konrad (2004) also deal with merger policy in a strategic trade context.
} 
There is plenty of evidence that multinational firms exploit the potential for shifting production across plants in different countries. Marginson and Schulten (1999) document in detail how plants within multinational firms are engaged in internal (but cross-country) competition for production and also future investments in industries, such as automobile, electronics and food manufacturing. ${ }^{13}$ However, when we turn to the econometric evidence on the effect of (domestic) mergers on wages, results become more blurred. Brown and Medoff (1988), Cremieux and Van Audenrode (1996) and Peoples, Hekmat and Moini (1993) find support for a wage cut following a merger, while McGuckin and Nguyen (2001) find the opposite result. Hekmat (1995) find no or only limited evidence of a link between takeovers and wages. Finally, Gugler and Yurtoglu (2004) find that mergers have no effect on employment in the US while it leads to lower employment in Europe, which might have to do with the degree of pre-merger wage flexibility. Our interpretation is that this body of empirical research simply is not tailored to answer the sharper question if mergers in industries with market power can depress union wages. Perhaps theoretical developments can be an inspiration for further empirical work on the merger-wages question. Further, there is a substantial empirical literature on the foreign ownership wage premium. On the surface, in many countries workers tend to earn more in foreign-owned firms, seemingly at odds with the theoretical model developed here. Almeida (2007) uses a matched employer-employee data set from Portugal, and finds that the seemingly high wages in foreign owned firms has more to do with 'cherry picking' in the selection of takeover targets than human capital development and wage increases in firms having been bought. Heyman, Sjöholm and Tingvall (2007) also use such matched data, this time from Sweden. They find comparatively small wage premia associated with various forms of foreign ownership, and in the case of takeovers of Swedish firms the effect on wages is zero or negative. Girma and Görg (2007) report, from a British data

\footnotetext{
${ }^{13}$ See also Lommerud, Straume and Sørgard (2006) for more examples and further discussion.
} 
set, substantial heterogeneity in the post-acquisition wage effect depending on the nationality of the acquirer and the skill group of workers. Again, this empirical work is not particularly tailored to the question raised here.

Almost no policy maker would take the stance that all international mergers are harmful. Sometimes a foreign takeover means that the local subsidiary can be developed in a better way and that the human capital of the employees is strengthened. Our model focuses on a case where workers secure high wages because their firms have market power, and where international mergers may threaten this position. All conclusions are of course then relative to this framework and we wish to make no bold statement about the aggregate foreignownership wage effect in society.

The paper unravels as follows. Section 2 presents the model framework. Then Section 3 analyses how firms arrive at a choice between merging domestically or internationally, and evaluates the situation from a policy maker's viewpoint. Section 4 then introduces the possibility of capital flight, in the sense that a firm physically moves its production abroad. This added option turns out to be crucial for the analysis. Different extensions of the main model are considered in Section 5 while Section 6 offers some concluding remarks.

\section{The model}

Consider an industry where, initially, three firms (single-plant owners) each produce a single (differentiated) good for a common international market. Two of the firms (1 and 2) are located in the "domestic" country, whilst the third firm is located elsewhere. We have in mind an international market where domestic consumption is negligible relative to global consumption. Thus, for simplicity, we abstract from domestic consumption altogether by applying a pure third-market model. The inverse demand facing firm $i$ is given by 
$p_{i}=a-q_{i}-b \sum_{j \neq i} q_{j}$

where $a$ is a positive constant, $b \in(0,1)$, is an inverse measure of the degree of product differentiation, and $q_{i}$ is supplied quantity of variety $i$.

The firms have similar technologies, characterised by a Leontief production function of the form $q_{i}=\min \left\{l_{i}, k_{i}\right\}$, where $l_{i}$ and $k_{i}$ are, respectively, the labour and capital employed by firm $i$. Labour costs are $w_{i}$ and capital costs are $c\left(1-\sigma_{i}\right)$ per unit. Firm $i$ 's marginal costs are thus given by

$m_{i}=w_{i}+c\left(1-\sigma_{i}\right)$

where $\sigma_{i}$ is a binary variable reflecting exogenous domestic merger synergies. We assume that a domestic merger yields an exogenous marginal cost saving equal to $\sigma c$, where $\sigma \in[0,1] .{ }^{14}$ Thus, the variable $\sigma_{i}$ is defined as $\sigma_{i}=\left\{\begin{array}{llc}\sigma & \text { if } & \text { firm i participates in a domestic merger } \\ 0 & \text { if } & \text { firm i does not participate in a domestic merger }\end{array}\right.$.

\footnotetext{
${ }^{14}$ We want to depict a situation where a domestic merger yields higher exogenous costs savings than does a cross-border merger. This is most easily represented by assuming that only a domestic merger yields exogenous cost savings. The assumption of higher domestic than cross-border synergies is not necessary to create a benign environment for national champion policy. The assumption on the welfare function will suffice, but the present assumption tilts the balance towards merger patriotism even more. We think it is highly industry-specific what synergies are actually the larger. If an industry for example has large distribution networks, national mergers could eliminate overlapping investments the most. If we are talking about high-tech industries, cross-border mergers where one of the countries has access to superior technology could create most synergies. As mentioned we have chosen to work with the present assumption because it most starkly highlights that national champion policy might not be a good idea even if the environment strongly should seem to suggest otherwise.
} 
We assume that domestic firms face an industry-wide monopoly trade union, while the foreign firm, operating in a non-unionised environment, has access to labour at a wage rate $\bar{w}<a-$ $c$. We want to portray a situation where domestic (unionised) firms have a cost disadvantage, and this is most easily done by setting the domestic reservation wage equal to $\bar{w}$.

The domestic union is a rent-maximiser. With the added assumption that the union is able to set different wages at different domestic firms/plants, union utility is given by

$U=\sum_{i \in N}\left(w_{i}-\bar{w}\right) q_{i}$

where $N$ is the set of domestic plants. We apply the traditional monopoly union framework, where wages are unilaterally set by the monopoly trade union prior to the firms' employment decisions. The firms are assumed to compete in quantities á la Cournot, with profits from plant $i$ given by

$\pi_{i}=\left(p_{i}-m_{i}\right) q_{i}$

\section{Domestic versus cross-border merger}

We assume that, in addition to the benchmark oligopoly market structure, there are two feasible merger options in the industry: a domestic merger or a cross-border merger. For simplicity, assume that both options involve firm $1 .{ }^{15}$ In other words, we let firm 1 choose

\footnotetext{
${ }^{15}$ Even though we shortly will introduce elements from endogenous merger theory, fixing attention on the possibilities of one particular firm is reminiscent of the traditional exogenous merger theory in the path of Salant, Switzer and Reynolds (1983) and Deneckere and Davidson (1985).
} 
between merging domestically with firm 2 and merging cross-border with firm $3 .{ }^{16}$ We assume that, post-merger, it is not possible to move the production of one brand from one plant to another. Thus, the quintessence of a merger is a coordination of output decisions among the merger participants.

In order to solve for the equilibrium market structure, we apply the endogenous merger formation model of Horn and Persson (2001b), where the merger process is treated as a cooperative game where the merger candidates are free to communicate and write binding contracts. Using the core as solution concept, an equilibrium market structure is a market structure that is undominated, in terms of joint profits of the decisive owners, by any other possible market structure. Allowing for side payments within, but not between, coalitions, the decisive owners are the group of owners that are able to influence whether market structure $M_{i}$ will be formed instead of $M_{j}$ and vice versa. More precisely, the group of decisive owners, when comparing $M_{i}$ and $M_{j}$ are the owners that belong to different coalitions in $M_{i}$ and $M_{j} .{ }^{17}$ In our specific case, there are three market structures to consider: oligopoly $\left(M_{O}\right)$, domestic merger $\left(M_{D}\right)$ and cross-border merger $\left(M_{C}\right)$. For instance, if we compare the cross-border merger with the domestic merger, firms 1 and 3 belong to a coalition in the former case, while firms 1 and 2 belong to a coalition in the latter. All three firms are then able to influence the choice between the two - the intuitive argument is that firm 3 (firm 2) may give up some profit to attract firm 1 to form a cross-border merger (domestic merger), and therefore both these firms are decisive. Quite obviously, firm 1 will also be decisive. $M_{D}$ is then undominated by $M_{C}$ if the sum of all profits under market structure $M_{D}$ is at least as large as the sum of all profits

\footnotetext{
${ }^{16}$ In line with previous related literature, we exclude the possibility of full monopolisation of the industry. A market structure involving a merger among all firms is both less interesting and, in any case, unlikely to be sanctioned by antitrust authorities.

${ }^{17}$ See Horn and Persson (2001b) for details of the theoretical underpinnings, including a formal definition of decisive owners.
} 
under $M_{C}$. Following this kind of reasoning, comparing $M_{O}$ and $M_{D}$, only firms 1 and 2 are decisive, while in the comparison between $M_{O}$ and $M_{C}$, only firms 1 and 3 are decisive.

\subsection{Merger effects on domestic wages and employment}

Before solving for the equilibrium market structure, let us first see how different types of mergers affect domestic wages and employment. The Nash equilibrium outcomes, in terms of production (employment), wages and profits, are reported, for each market structure, in Appendix A. Letting $w_{i}^{k}$ denote the equilibrium wage level at plant $i$ in market structure $M_{k}$, we derive a clear-cut ranking of wage level across the different market structures:

Proposition 1. $w_{i}^{D} \geq w_{i}^{O}=w_{2}^{C}>w_{1}^{C}, i=1,2$.

Compared with the benchmark oligopoly equilibrium, only a domestic merger will lead to a wage increase (for $\sigma>0$ ). A cross-border merger, on the other hand, will lead to reduced wages, but only at the domestic plant of the merged firm. Although the model set-up is somewhat different, the intuition for these results is for the most part similar to what is explained in great detail in Lommerud, Straume and Sørgard (2006). Here, we will just summarise the main mechanisms. A cross-border merger allows, to a certain extent, the merged unit to replace domestic (high-cost) production with foreign (low-cost) production. ${ }^{18}$ This increases the labour demand elasticity at the domestic plant and forces the domestic union to lower the wage in order to mitigate job losses. The strength of this effect depends on

\footnotetext{
${ }^{18}$ Note that this does not imply that production capacity is moved from one country to another, which is blocked by assumption. Rather, it is to some extent possible to meet market demand by scaling up production at the low-cost location and scaling down where costs are higher. Remember that the products at different locations are only imperfect substitutes, which offers some degree of shelter from competition to the high-cost provider.
} 
the degree of product differentiation. The less differentiated products are, the easier (less costly) it is for the merged unit to replace domestic with foreign production. Thus, a crossborder merger works as a wage disciplining device towards the domestic trade union, and more so the less differentiated the products of the merging parties are. A domestic merger, on the other hand, does not have this effect on union wage demand, since the trade union controls labour supply at both plants. In fact, in the absence of any exogenous merger synergies, a domestic merger has no effect on union wage demand. ${ }^{19}$ However, when there are other variable cost synergies of a merger, there will be a positive labour demand response causing wages to increase. Thus, for $\sigma>0$, a domestic merger leads to higher wages.

The corresponding domestic employment effects of merger depend, in part, on the size of the domestic merger synergies. Let $L^{k}:=\sum_{i \in N} l_{i}^{k}$ denote total employment at domestic plants in market structure $M_{k}$. Furthermore, let $S:=\frac{\sigma c}{a-\bar{w}-c}$ be a measure of exogenous domestic merger synergies. Three different scenarios can be identified:

\section{Proposition 2.}

(i) If $S \leq \frac{b}{4^{\prime}}$, then $L^{O}>L^{C} \geq L^{D}$.

(ii) If $S \in\left(\frac{b}{4}, \frac{b}{2(1+b)}\right]$, then $L^{O} \geq L^{D}>L^{C}$.

(iii) If $S>\frac{b}{2(1+b)^{\prime}}$, then $L^{D}>L^{O}>L^{C}$.

Compared with the benchmark oligopoly equilibrium, a cross-border merger always reduces domestic employment. Thus, the wage drop at the domestic plant is not sufficient to fully compensate for the drop in domestic labour demand. The employment effect of a domestic merger, on the other hand, depends crucially on the amount of cost synergies. If these are

\footnotetext{
${ }^{19}$ This is a quite general result; see Dhillon and Petrakis (2002).
} 
small, a domestic merger will reduce employment even more than a cross-border merger. On the other hand, for sufficiently large cost synergies, the market structure with a domestic merger yields the highest level of domestic employment.

\subsection{Equilibrium market structure}

In our specific model, for a market structure involving a merger to be undominated, and thus constitute an equilibrium market structure, two conditions must be jointly fulfilled: (i) the merger must be privately profitable for the merger participants, and (ii) the merger must generate higher total industry profits than in any of the alternative market structures. The second condition follows from the fact that, when comparing the two market structures involving a merger, $M_{C}$ and $M_{D}$, all three owners are decisive. Assuming that antitrust authorities will allow any of the two considered merger proposals, the following result obtains:

Proposition 3. Under a laissez-faire merger policy, there is always a merger in equilibrium. The equilibrium market structure is $M_{C}\left(M_{D}\right)$ if $S<(>) S_{C D}$, where

$$
S_{C D}:=\frac{3 b(1+b)-b^{3}-2+\sqrt{8+(2-b) b\left(3 b^{2}\left(3+b-b^{2}\right)-2\right)}}{2\left(b+b^{2}+1\right)} .
$$

A formal proof simply contains straightforward profit comparisons between different market structures and is thus omitted. It is more instructive to go through the different steps of the proof intuitively. Due to the wage-reducing effect of a cross-border merger, such a merger is always privately profitable and, naturally, also increases total industry profits. Thus, we can rule out the benchmark oligopoly as an equilibrium outcome of the merger process. Whether firm 1 will merge cross-border or domestically depends on which type of merger that generates higher industry profits. This depends, in turn, on the magnitude of cost savings. Since a cross-border merger induces a wage cut, while a domestic merger leads to a wage 
increase, the latter type of merger yields higher industry profits only if the exogenous merger synergies are sufficiently large; more precisely, if $S>S_{C D}$. A merger synergy of this magnitude also ensures that the domestic merger is privately profitable. A closer scrutiny of the threshold value, $S_{C D}$, reveals that it is positive and increasing in $b$. Thus, the scope for a domestic merger is lower in industries with a low degree of product differentiation. The reason is that the wage disciplining effect of a cross-border merger is higher the lower the degree of product differentiation, implying that the attractiveness of such a merger is increasing in $b$.

\subsection{Domestic merger policy}

Let us now introduce a domestic policy towards mergers. ${ }^{20}$ In order to study policy issues we need to endow policy makers with an objective function. We assume that they care more about the well-being (wages and employment possibilities) of domestic workers than other domestic agents, as consumers and owners of firms. As noted in the introduction, this assumption gives the national champion argument a fair chance - and our main result is that even in an environment as benign for merger patriotism as this, national champion merger

\footnotetext{
${ }^{20}$ We should stress that what we refer to as merger policies not necessarily are official merger policies rooted in competition laws. Competition laws typically put substantial weight on consumer welfare. Politicians who want a nationalistic merger policy typically will have to resort to hints, media statements and the like. In Norway, the first merger law was introduced in 1992. The first years almost every attempt by the competition authorities to block a merger was overturned by appeal to the relevant ministry - where the minister in question was recruited from the trade union movement. In Finland cartels were allowed until the early 1990s, and Hyytinen, Steen and Toivanen (2010) find that towards the end of this period almost all industries were cartelised. We think it fair to say that in many European countries official merger policy is a by-product of EU membership, and not necessarily something which is embraced by national politicians with enthusiasm.
} 
policy can be very problematic. We do, however, think that the assumption that jobs are very important for policy makers has some merit as a realistic description of some economies. Producer interests are often better organized than consumer interests. In the countries of Northern Europe, the development of the trade union movement was closely linked to the growth of social democratic parties. ${ }^{21}$ Even in countries with weak unions, like the US, shocks to employment will typically hurt in a geographically concentrated way, so politicians from these particular constituencies will typically have to lobby for policies to preserve local jobs. Benefits for consumers are often spread out thinly across the whole economy. Capital owners can be well organized, but one reason why capital income counts less in a welfare function is that ownership of firms increasingly is global. ${ }^{22}$ We first take this argument to the extreme by assuming that the objective of the domestic policy maker is simply to maximise domestic union rents, i.e., domestic welfare in market structure $M_{k}$ is given by $W^{k}:=U^{k}$. Later we extend the model by assuming that consumers can reside in the home country and carry some weight in the welfare function. In principle, also capital owners could be included in the welfare function. The essential assumption is that the well-being of workers is weighted more heavily in the welfare function than outcomes for other groups, not that these other groups do not count at all.

\footnotetext{
${ }^{21}$ If we take Norway as an example, for many decades membership of many trade unions under the LO umbrella (the blue collar trade union confederation) also implied membership in the social democratic party. The leader of the election committee when the leadership of the social democratic party was nominated was traditionally the leader of LO. In Britain, were parties do not receive public funds for campaigning, contributions from the trade union movement are all important for the Labour party.

${ }^{22}$ In a small open economy like Norway - after deducting shares owned by the Norwegian state foreign ownership of stocks listed at the Oslo stock exchange fluctuates around $50 \%$.
} 
By comparing the different market structures we can identify two alternative welfare rankings, depending on whether domestic merger synergies are below or above a certain threshold level. Let

$S^{*}:=\frac{\sqrt{(2-b)(1+b)\left(2(1+b)-b^{2}\right)}-2-b-b^{2}}{2(1+b)}$.

It is straightforward to verify that $\partial S^{*} / \partial b>0$ on the interval $(0,1)$ and that $\lim _{b \rightarrow 1} S^{*}=$ $12232-1 \approx 0.11$. We can then make the following domestic welfare rankings:

Proposition 4.

(i) If $S \leq S^{*}$, then $W^{O} \geq W^{D}>W^{C}$.

(ii) (ii) If $S>S^{*}$, then $W^{D}>W^{O}>W^{C}$.

A cross-border merger is always the least preferred market structure, from the viewpoint of the domestic policy maker, due to the merger-induced downward pressure on domestic wages. A domestic merger, on the other hand, enables the domestic wage level to increase, while the employment effect is ambiguous. This is the most preferred market structure if the exogenous cost synergies are sufficiently high. The implications for optimal merger policy are straightforward:

Corollary 1. A cross-border merger proposal will never be accepted. A domestic merger proposal will be accepted if the merger synergies are sufficiently high: $S>S^{*}$.

If domestic merger synergies are low $\left(S<S^{*}\right)$, all merger proposals will be declined.

Otherwise, for $S>S^{*}$, the domestic policy maker will decline a cross-border merger proposal, 
but accept a domestic merger proposal. In the following, we will refer to this as a national champion policy.

How is the domestic merger policy going to affect the equilibrium market structure? Ruling out the possibility of cross-border merger, we are left with only two possible market structures: $M_{O}$ or $M_{D}$. The equilibrium is then simply determined by the private profitability of a domestic merger. The relevant profit comparison $\left(\pi_{1}^{D}+\pi_{2}^{D}\right.$ vs. $\left.\pi_{1}^{O}+\pi_{2}^{O}\right)$ shows that a domestic merger is profitable if

$S>S_{D O}:=\frac{\sqrt{(b+1)^{3}}\left(2+2 b-b^{2}\right)-(2-b)(b+1)^{3}}{2(b+1)^{3}}$.

It is straightforward to verify that $S_{D O}<S^{*}<S_{C D}$ for all $b \in(0,1)$. This enables us to characterise the optimal domestic merger policy and its effects as follows:

\section{Proposition 5.}

(i) If $S>S_{C D}$, merger policy is redundant. The outcome is a domestic merger in any case.

(ii) If $S^{*}<S \leq S_{C D}$, the optimal policy is a national champion policy. The outcome is a domestic merger instead of a cross-border merger.

(iii) If $S \leq S^{*}$, the optimal policy is to decline all merger proposal. The outcome is oligopoly instead of a cross-border merger.

In terms of deriving a rationale for a national champion policy, Regime (ii) is clearly the interesting case. It shows that, for intermediate levels of domestic merger synergies, a national champion policy is both optimal and effective: by blocking any cross-border merger proposals, a domestic policy maker can induce a domestic merger, thereby increasing domestic welfare. There are, however, cases where all mergers should be blocked. 


\section{Capital flight}

Assume now that, in addition to the two merger alternatives, firm 1 has a third feasible option: capital flight. Consider the case where firm 1 can set up a plant in a foreign non-unionised location at a fixed investment cost $f \cdot{ }^{23}$ We assume that such a relocation of production will give the investing firm access to labour at a wage rate $\bar{w}$. The relocated firm continues to produce the same variant of the product in question as before, so the degree of product differentiation among the products of the three plants remains the same. The relocation option creates a fourth possible market structure, denoted $M_{F}$, with an oligopoly consisting of one high-cost (unionised) and two low-cost (non-unionised) firms. ${ }^{24}$

Let us first see how capital flight affects domestic wages and employment, compared with the previously discussed market structures. Again, using the equilibrium expressions reported in the Appendix, the effect of capital flight by one of the domestic firms can be characterised as follows:

\footnotetext{
${ }^{23}$ As noted in the Introduction there is a series of papers that study the pros and cons of different entry modes into a foreign market. What we have dubbed 'capital flight' is very close to what usually is called greenfield entry. Capital flight means that a new production facility is built up greenfield in the other country - but there is also the assumption that the production capacity in the original country is closed. However, in our particular model set-up it would never be profitable to continue operating at home once the foreign operation is set up, so in this context capital flight and greenfield entry are more or less the same concept.

${ }^{24}$ In order to keep the analysis reasonably simple and focussed, we rule out the possibility of combining two of the options; i.e., we rule out the possibility of merging and relocating production.
} 


\section{Proposition 6.}

(i) Compared with the benchmark oligopoly outcome, capital flight by one domestic firm causes the wage level in the remaining domestic firm to drop to a level $w^{F} \in\left(w_{1}^{C}, w_{i}^{O}\right)$.

(ii) Compared with all other market structures, capital flight always reduces domestic employment.

(iii) Capital flight is the market structure associated with the lowest welfare level.

Proofs are straightforward given the expressions in Appendix A.

If we compare with the benchmark oligopoly, capital flight by one domestic firm implies that the remaining domestic firm faces tougher competition, since it becomes the only high-cost firm in the industry. This, in turn, induces the union to lower its wage demand in order to stimulate domestic employment. However, in terms of total domestic employment, the direct job losses brought about by capital flight can, unsurprisingly, never be compensated by output expansion in the remaining domestic firm. Since capital flight leads to severe job losses and relatively low wages for the remaining domestic workers, this option yields the lowest level of welfare.

In the following, we will assume, as before, that the authorities are able to block proposed mergers, domestic or cross-border. However, we think it would be unreasonable to assume that the domestic policy maker is able directly to prevent firm 1 from fleeing the country and relocating production elsewhere. Capital flight is thus a viable alternative for firm 1 whatever any government might think of it. 


\subsection{Laissez-faire equilibria}

How is the option of capital flight for firm 1 going to affect the equilibrium market structure? We incorporate the capital flight option into the Horn-Persson framework by treating it as a new market structure, akin to the oligopoly benchmark. Each of the previously considered market structures must now be compared with the capital flight option. For example, $M_{D}$ will be undominated by $M_{F}$ if it is possible for firm 2 and firm 1 to agree on a domestic merger deal that makes both firms better off than if firm 1 decides to flee the country. In other words, $M_{D}$ is undominated by $M_{F}$ if $\pi_{1}^{D}+\pi_{2}^{D}>\pi_{1}^{F}+\pi_{2}^{F}$, and vice versa. Comparing merger structure $M_{C}$ with $M_{F}$ requires a similar approach (firms 1 and 3 are decisive). For capital flight to occur in equilibrium, this option must obviously also be privately profitable for firm 1, i.e., $\pi_{1}^{F}>\pi_{1}^{O}$. In Horn-Persson parlance, this means that the capital flight option is undominated by the benchmark oligopoly for the decisive owner - which is firm 1 .

In order to derive the equilibrium outcome, we need to make use of the following partial results.

\subsubsection{Capital flight versus cross-border merger}

Compared with capital flight by firm 1 a cross-border merger yields higher joint profits for the merger candidates if the relocation costs are sufficiently high. ${ }^{25}$ More precisely, $\pi_{1}^{C}+\pi_{3}^{C}>$ $\pi_{1}^{F}+\pi_{3}^{F}$ if

\footnotetext{
${ }^{25}$ A cross-border merger and capital flight (greenfield entry into the foreign market) are not perfect substitutes in this model. Remember that the various plants produce horizontally differentiated variants of the good in question. A cross-border merger gives Firm 1 access to a production facility abroad that produces a different variety. This has its advantages, but the wage discipline effect is reduced by the fact that the firm would not want to cut back production of the home variety too much, as it has its
} 
$\varphi>\varphi_{F C}:=\frac{48+128 b-4 b^{2}-212 b^{3}-86 b^{4}+84 b^{5}+37 b^{6}-10 b^{7}-3 b^{8}}{16(2+b)^{2}(1+b)^{2}\left(2+2 b-b^{2}\right)^{2}}$,

where $\varphi:=f /(a-\bar{w}-c)^{2}$ is a measure of the fixed investment costs associated with capital flight.

It is straightforward to verify that $\partial \varphi_{F C} / \partial b<0$ on $(0,1)$. Furthermore, $\varphi_{F C}<0$ if $b>0.94$. This means that, even if capital flight is costless, a cross-border merger still yields higher joint profits if products are close to homogeneous $(b>0.94)$. Not only is the gain of capital flight lower in industries with little product differentiation, but the effectiveness of cross-border merger, in terms of reducing domestic wages, is that much higher.

In the following, we will assume that the above restriction holds, so that, in all cases discussed, a cross-border merger will be chosen over capital flight if the merger option is available. This helps reduce the number of cases discussed, but more importantly, since we will be discussing the banning of cross-border mergers as in the previous section, it is less interesting to discuss cases where capital flight is chosen over a cross-border merger in any case.

\subsubsection{Capital flight versus the oligopoly benchmark}

The private profitability of capital flight (firm 1 is the decisive owner) obviously depends on the magnitude of relocation costs. A simple profit comparison reveals that $\pi_{1}^{F}>\pi_{1}^{O}$ if

$\varphi<\varphi_{F O}:=\frac{2 b+3}{4(b+1)(b+2)^{2}}$.

customer basis. Capital flight, on the other hand, means to set up production abroad of the same variety that hitherto was produced at home. This does not satisfy consumer tastes for variety, but is very good for keeping wage costs down. 
Since $\frac{\partial \varphi_{F O}}{\partial b}<0$ on the interval $(0,1)$, it follows that capital flight is less likely to be a profitable option the less differentiated products are. This is quite intuitive, since less differentiation (i.e., more competition) reduces domestic wages and thereby reduces the gain of capital flight.

Also, $\varphi_{F O}>\varphi_{F C}$, thus even though we have assumed cross-border merger to be chosen over capital flight, whether oligopoly yields higher or lower profits than capital flight for the decisive owners, is still an open question. This can be traced back to the fact that a cross-border merger is always chosen over oligopoly, due to the wage reductions involved when firms merge internationally.

\subsubsection{Capital flight versus domestic merger}

In qualitative terms, a domestic merger yields higher profits for the domestic firms if the ratio between merger synergies and relocation costs is sufficiently high. Solving for $\pi_{1}^{D}+\pi_{2}^{D}<$ $\pi_{1}^{F}+\pi_{2}^{F}$ (firms 1 and 2 are decisive) we obtain

$\varphi<\varphi_{F D}:=\frac{1}{8} \frac{10+14 b+5 b^{2}}{(1+b)^{2}(2+b)^{2}}-\left(\frac{1+b}{8}\right)\left(\frac{2-b+2 S}{2-b^{2}+2 b}\right)^{2}$.

We are now ready to characterise the market structure equilibria, assuming again that any of the two considered merger proposals will always be sanctioned by antitrust authorities.

Proposition 7. Under a laissez-faire merger policy, and assuming $\varphi>\varphi_{F C}$, Proposition 3 still holds.

Proof. We have already established this result for the case where production cannot be relocated. Since we have assumed that $\varphi>\varphi_{F C}$, there cannot be capital flight in equilibrium. To establish that the two merger options still constitute equilibrium market structures, we need to check that we cannot be in a situation where $M_{D} \operatorname{dom} M_{C} \operatorname{dom} M_{F} \operatorname{dom} M_{D}$, which would imply nonexistence of equilibrium (transitivity is not ensured with the Horn-Persson 
framework since the decisive owners are not the same in all pair-wise comparisons).

$M_{D}$ dom $M_{C}$ for $S>S_{C D}$. To check that we cannot simultaneously have $M_{F}$ dom $M_{D}(\varphi<$

$\left.\varphi_{F D}\right)$, notice that $\varphi_{F D}$ is decreasing in $S$ so that, for $S>S_{C D}, \varphi_{F D}(S)<\varphi_{F D}\left(S_{C D}\right)$. Now it is straightforward to show that $\varphi_{F D}\left(S_{C D}\right)<\varphi_{F C}$ for all $b$, so that the inequalities $\varphi<\varphi_{F D}\left(S_{C D}\right)$ and $\varphi>\varphi_{F C}$ cannot be satisfied simultaneously. Thus Proposition 3 still applies. Q.E.D.

The assumption $\varphi>\varphi_{F C}$ then seems effectively to prevent capital flight as an option. By including $\varphi<\varphi_{F C}$, we could determine a region of the parameter space where capital flight is the equilibrium ownership structure. However, since our focus is merger policies, and we have assumed that capital flight cannot be prevented, there will certainly be no change in firm behaviour due to merger policies if capital flight is the first-best option. We therefore highlight the most interesting case, which is $\varphi>\varphi_{F C}$, and as we shall see, although capital flight is not the premier choice of market structure, this option can change the scope of merger policies dramatically.

\subsection{The scope for a national champion policy}

The interesting question in this context is how the possibility of capital flight affects the optimal domestic merger policy; in particular, if and how it affects the scope for a national champion policy. The next proposition describes the possibilities for merger policy.

Proposition 8. Given that $\varphi>\varphi_{F C}$, the scope for domestic merger policies is as follows:

(i) Merger policy is redundant if $S>S_{C D}$.

(ii) A national champion policy is effective and optimal if (I) $\varphi>\varphi_{F D}$ and $S \in$ $\left(S^{*}, S_{C D}\right)$, and if (II) $S<S^{*}, \varphi>\varphi_{F D}$ and $\varphi<\varphi_{F O}$. 
(iii) A ban on all mergers is effective and optimal for $S<S^{*}$ and $\varphi>\varphi_{F O}$.

(iv) National champion policies or a ban on all mergers are ineffective and counterproductive for $\varphi<\varphi_{F D}$ and $\varphi<\varphi_{F O}$.

Proof. (i) The result follows from Corollary 1 and Proposition 7 since $S_{C D}>S^{*}$ for all $b \in$ $(0,1)$. (ii) Part I: For $S \geq S^{*}$ a domestic merger is the best outcome for the authorities. For $\varphi>\varphi_{F D}$, a domestic merger is chosen over capital flight. Since $S_{D O}<S^{*}$, a domestic merger is also preferred to oligopoly by the decisive owners for $S>S^{*}$. Thus, when banning a crossborder merger, a domestic merger is the result. Part II: Here the authorities would have liked to see oligopoly rather than a domestic merger, but banning both merger types will induce capital flight rather than oligopoly $\left(\varphi<\varphi_{F O}\right)$. (iii) For $S<S^{*}$, welfare is highest with oligopoly. For $\varphi>\varphi_{F O}$, oligopoly is chosen over capital flight. (iv) Here capital flight is chosen over both oligopoly and a domestic merger, so if the cross-border merger is prevented, the result is capital flight, which yields lower welfare than any of the other options. Q.E.D.

Below we illustrate the above Proposition, assuming $\varphi=0.08$. The figure gives the correct qualitative picture for $\varphi \in(0.07,0.1)$. Other cases are briefly discussed in Footnote 25 . Note that we have manipulated the vertical axis to make the figure easier to read. 


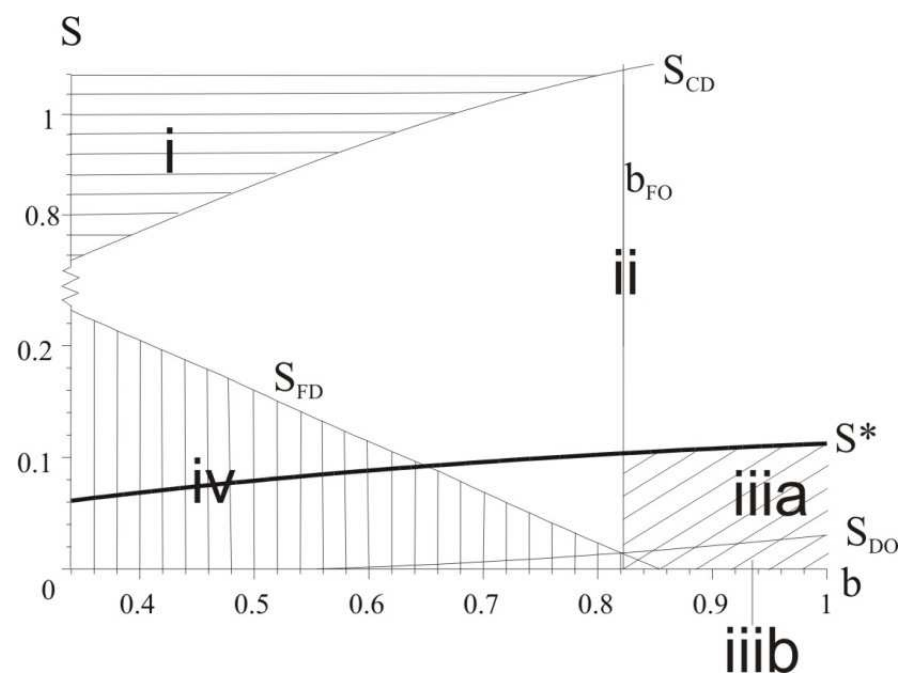

Figure 1: Optimal merger policy

$S_{F D}$ is constructed based on $\varphi_{F D}$. For a given value of $\varphi$ (here $\varphi=0.08$ ), $\varphi_{F D}$ gives $S$ as a function of $b$. Above $S_{F D}$, a domestic merger is preferred to capital flight by the decisive owners since merger synergies are high. $b_{F O}$ is a similar construct: for the given value of $\varphi, b$ has to be above a certain level for oligopoly to be preferred to capital flight for firm 1 (see Section 4.1.2). Finally, since we have assumed cross-border merger to be preferred to capital flight, $b$ cannot be very low (except when relocation costs are high - see footnote 25 and also the discussion in Section 4.1.1).

In region (i), the laissez-faire equilibrium is a domestic merger, while in regions (ii)-(iv), a crossborder merger emerges as the equilibrium outcome (Proposition 7). The scope for domestic merger policy - in particular, a national champion policy - is then as follows:

- Region (i): Merger policy is redundant since we are in a region where domestic merger is the best outcome for the authorities $\left(S>S^{*}\right)$.

- Region (ii): We see that a domestic merger is chosen over capital flight and a domestic merger is also chosen over oligopoly, i.e., a ban on cross-border mergers will induce a domestic merger. In the region $S \in\left(S_{F D}, S^{*}\right)$ and $b<b_{F O}$, the 
authorities would prefer oligopoly to a domestic merger, but trying to induce oligopoly by blocking both types of merger will lead to capital flight. Thus, in region (ii), a national champion policy is effective and optimal.

- Region (iiia): As in region (ii), preventing a cross-border merger induces a domestic merger. However, the authorities would rather induce oligopoly, which is a possibility in this case. By blocking all mergers, oligopoly is chosen over capital flight. Thus, in region (iiia) blocking all mergers is optimal.

- Region (iiib): For the firms, oligopoly is the preferred outcome when a cross-border merger option is taken off the table. Furthermore, oligopoly is the best option seen from a welfare perspective. Blocking a cross-border merger will here be optimal. Also, blocking a national merger makes no difference.

- Region (iv): Here capital flight is chosen over a domestic merger, and also over oligopoly. Thus, banning a cross-border merger will induce capital flight, and additionally banning a domestic merger has no effect on outcomes. Domestic merger policy is here counterproductive. ${ }^{26}$

\footnotetext{
${ }^{26}$ Figure 1 correctly represents the situation for $\varphi \in(0.07,0.1)$. Outside this region, the following differences apply:

- For $\varphi \in(0,0.07)$ only regions (i), (ii) and (iv) exist $\left(b_{F O}>1\right)$. Since $\varphi_{F C}$ is decreasing in $b$, a lower level of $\varphi$ will increase the critical level of $b$ above which our results are valid. For $\varphi=0$, $b>0.94$ is required. For $\varphi=0.08$ (as in Figure 1 ), $b>0.34$ is required.

- For $\varphi \in(0.1,(3 / 16))$, the picture would more closely resemble that of Figure 1 . The only difference is that regions (ii) and (iiia) can also happen for $S=0$ for intermediate values of $b$.

- For $\varphi=3 / 16, b_{F O}=0$. For $\varphi \geq 3 / 16$, all other options are better for the decisive owners than capital flight, so the results of the previous section (no capital flight) applies for all $S$ and $b$.
} 
While in Figure 1, we have "blown up" the low-S parameter space, we would argue that this typically holds the most relevant cases. $S$ is defined as $\frac{\sigma c}{a-\bar{w}-c}$, with $\sigma$ less - and probably most often far less - than unity. Furthermore, $a-\bar{w}-c$ is (with the usual interpretation) the maximum willingness to pay net of unit production costs. Realistically, this would be far greater than the per unit synergies, $\sigma c$. Consequently, the low- $S$ space would typically be the most relevant.

Besides the fact that the possibility of capital flight may decrease the attractiveness of using merger policies, we can also say something about when merger policies can be expected to be less worrisome. Of course, higher relocation costs will reduce the relative attractiveness of capital flight, reducing the problem that could potentially make merger policies backfire. Similarly, higher synergies make the domestic merger alternative more likely relative to all other market structures. This reduces the possibility that banning cross-border mergers may induce capital flight, but at the same time, it increases the possibility that merger policies are redundant. Beyond these relatively obvious results, we can also deduce the following:

Corollary 2. Less product differentiation increases the possibility that merger policies are effective and optimal.

Proof. Merger policies are effective in cases (ii) and (iii) in Proposition 8, i.e., for $\varphi>$ $\max \left(\varphi_{F O}, \varphi_{F D}\right)$ and $S<S_{C D}$. The above result then follows from the fact that $S_{C D}$ is increasing in $b$ (making a cross-border merger more likely in the laissez-faire case) while $\varphi_{F D}$ and $\varphi_{F O}$ are decreasing in $b$ (shrinking the parameter space for which a merger policy will backfire). For a proof of the fact that $\varphi_{F D}$ is decreasing in $b$ (the only part not proven earlier), see Appendix B. Furthermore, $\varphi_{F C}$ is also decreasing in $b$, so that the discussed parameter range is also increasing. Q.E.D. 
As previously discussed, the gains of a cross-border merger are higher in industries with less differentiated products, implying that $M_{C}$ is an equilibrium outcome for a larger set of parameter configurations, increasing the relevance of merger policy. At the same time, we know that less differentiated products (implying stronger competition) reduces, all else equal, the incentive for capital flight. This increases the likelihood that the most attractive alternative to a cross-border merger is a domestic merger or oligopoly, rather than capital flight by firm 1. Thus, the scope for a national merger policy is larger in industries with less product differentiation, and vice versa. All in all, the scope for a national merger policy is then industries where (i) relocation costs are sufficiently high, (ii) domestic merger synergies are at intermediate levels, and (iii) products are sufficiently close substitutes. Otherwise, blocking mergers might be ineffective and counterproductive; ineffective because blocking a crossborder merger will not induce a domestic merger or oligopoly, and counterproductive because it will induce an outcome that is even worse for the policy maker, namely capital flight.

Since the analysis is cast in the setting of global market competition, one might speculate how our results would be affected by globalisation. There are different aspects of globalisation that might pull in different directions with respect to the desirability and scope for national champion merger policies. One aspect of globalisation is an increase in the intensity of product market competition. As in Blanchard and Giavazzi (2003) we can think of the differentiation parameter $b$ as a measure of the degree of competition between firms. ${ }^{27}$ From the above

\footnotetext{
${ }^{27}$ Within a framework of monopolistic competition, Blanchard and Giavazzi make this interpretation on the parameter measuring the elasticity of substitution in a CES demand function, but there is of course a clear analogy to the differentiation parameter in a linear demand system. It is important to stress, though, that by interpreting a parameter change in a demand system as a result of globalisation (or other institutional changes), one should think of the parameter, in our case $b$, not as a taste parameter in a utility function but rather interpret the underlying utility function as a reduced form reflecting the
} 
analysis, it follows that this particular aspect of globalisation increases the scope for a national champion policy. However, globalisation also implies that it becomes easier to relocate production. In our model, this corresponds to a reduction in the FDI cost $f$, making capital flight a cheaper and thus more feasible option. Clearly, this will make it more likely that a national champion policy backfires and thus reduces the scope for such merger policies.

National champion policy often run contrary to official merger policy, as competition law tends to have the interests of consumers at heart, not unionised workers. One way policy makers could tilt merger decisions towards national alternatives would be to try to increase domestic merger synergies relative to cross-border ones. One may hypothesize that infrastructure investments or subsidies that encourage national technology coordination could play this role. ${ }^{28}$ If the threat of capital flight (through a reduction of $f$ ) should become more acute, this could be counteracted by a policy-induced increase in domestic merger synergies $(\sigma)$.

\section{Extensions}

In this section we analyse and discuss the robustness of some of our main robustness. We formally extend the model in two different directions. First, we assume that the domestic trade union is committed to a "wage solidarity" policy of setting a uniform wage for all domestic firms. Second, we assume that consumer surplus is included in the objective function of the policy maker. Finally, we also include an informal discussion of how the main mechanisms of the model will chance in the case of alternative (more decentralised) trade union structures.

substitutability among products. See also Lommerud, Meland and Straume (2009) for a similar interpretation.

${ }^{28}$ We thank a referee for suggesting this line of argument. 


\subsection{Wage solidarity}

So far we have assumed that the union can set different wages for workers in the two domestic firms. Here we will briefly discuss what happens if the union must set equal wages for all domestic workers. Because of the symmetry assumptions, this only affects the crossborder merger case. The outcomes are given in Appendix A. Under a wage solidarity policy, the union cannot choose the wages optimally to maximise total rents in the case of a cross-border merger, implying that union utility in this case is lower than if wages were allowed to be different across the domestic firms. However, in terms of union rents, a cross-border merger is still better than FDI, where production is relocated abroad. Also, the cross-border merger's negative impact on wages is lower, so the merger is less profitable for the merger participants under wage solidarity.

We restrict our attention to the case discussed in the main analysis, where there is always some sort of industry restructuring because a cross-border merger dominates oligopoly, and where a cross-border merger is chosen over FDI if the merger is allowed. Since a cross-border merger is less profitable under wage solidarity, this restricts the parameter space more than in the previous setting.

1. Using the expressions in Appendix A, we have that cross-border merger is chosen over oligopoly if $b<0.55776$.

2. If $b<0.55776$, cross-border merger is chosen over FDI if

$\varphi>\varphi_{F C e}:=\frac{\mu}{8(1+b)^{2}(2+b)^{2}\left(2+2 b-b^{2}\right)^{2}\left(8-4 b-b^{2}\right)^{2}}$, 
where $\mu:=1536+2816 b-3232 b^{2}-5312 b^{3}+4504 b^{4}+4568 b^{5}-2672 b^{6}-$ $1676 b^{7}+659 b^{8}+247 b^{9}-46 b^{10}-15 b^{11}$. For $b<0.55776, \varphi_{F C e}$ is positive and decreasing in $b$.

Keeping these two restrictions in mind, introducing wage solidarity only affects the dominance ranking between cross-border merger and domestic merger. Using the expressions in Appendix A, it is easy to show that a domestic merger is chosen over a cross-border merger if

$S>S_{C e D}:=\frac{\left(8-4 b-b^{2}\right)(2+b)\left(\sqrt{\tau}-(2+b)\left(8-4 b-b^{2}\right)\left(4-2 b-4 b^{2}+b^{3}\right)\right)}{2\left(2+2 b+b^{2}\right)}$,

where $\tau:=10240+15360 b-6016 b^{2}-15744 b^{3}-5536 b^{4}+896 b^{5}+5512 b^{6}+$

$1832 b^{7}-1216 b^{8}-504 b^{9}+80 b^{10}+36 b^{11}+b^{12}$.

Given the above two assumptions, we have

Proposition 9. Under wage solidarity, the laissez-faire equilibrium ownership structure is a cross-border merger for $S<S_{C e D}$ and a domestic merger otherwise.

Proof. The first part follows directly from the above calculations. For the second part, we need to show that for $S>S_{C e D}$, domestic merger also dominates FDI and oligopoly. For the first issue, it suffices (see the analogous proof of Proposition 8) that $\varphi_{F D}\left(S_{C e D}\right)<\varphi_{F C e}$, which can be shown to be true. For the second issue we need to show that $S_{C e D}>S_{D O}$, which is also the case. Q.E.D.

Thus, the basic situation is the same as before. In the laissez-faire case, there is either a domestic or a cross-border merger, depending on the size of the domestic merger synergies. If cross-border mergers are banned, the results are obviously exactly the same as before; there will be FDI, a domestic merger or no change in market structure, depending on the 
parameters. Given that the welfare ranking is also the same as before, and $S_{C e D}>S^{*}$, we therefore have

Proposition 10. Given that $\varphi>\varphi_{F C e}$, and $b<0.55776$, Proposition 9 still holds when we replace $S_{C D}$ with $S_{C e D}$.

Thus, the main results are qualitatively unaffected by assuming that the trade union adopts a wage solidarity policy. Notice, however, that $S_{C e D}<S_{C D}$, implying that the scope for national champion policy is lower here - the cross-border merger is less profitable and thus the policy to prevent it is redundant for a larger parameter space than before.

\subsection{Consumer welfare}

So far we have assumed that the objective of the domestic policy maker is to maximise domestic worker rents (union utility). Here we extend the analysis to include domestic consumption, implying that the policy maker also takes consumer welfare into account. We maintain the assumption that firm profits do not play enter the policy maker's objective function, as discussed earlier. The domestic welfare measure is now given by

$W=U+\alpha C S$,

where

$C S=a \sum q_{i}-\frac{1}{2} \sum q_{i}^{2}-b \sum_{i \neq j} q_{i} q_{j}-\sum p_{i} q_{i}=\frac{1}{2} \sum_{i=1}^{3} q_{i}^{2}+b\left(q_{1} q_{2}+q_{1} q_{3}+q_{2} q_{3}\right)$

is total consumer surplus in the market while $\alpha \in(0,1)$ is a weight that corresponds to the share of consumers residing in the domestic country. For simplicity, we set $\alpha=1 / 2$. 
The different values of $W$ in the different market structures are given in Appendix $A$. Using these, it is easy to verify that, in terms of domestic welfare, oligopoly dominates both FDI and cross-border merger:

$$
W^{O}-W^{F}=\frac{\left(20-8 b-3 b^{3}-9 b^{2}\right)(a-c-\bar{w})^{2}}{64(1+b)(2+b)^{2}}>0
$$

and

$$
W^{o}-W^{C}=\frac{b(2-b)\left(22+50 b+19 b^{2}-12 b^{3}-2 b^{4}\right)(a-c-\bar{w})^{2}}{64(1+b)^{2}\left(2+2 b-b^{2}\right)^{2}}>0 .
$$

The welfare ranking of FDI and cross-border merger is, however, ambiguous. A cross-border merger dominates FDI if

$$
\begin{aligned}
& W^{C}-W^{F} \\
& =\frac{\left(80+96 b-268 b^{2}-444 b^{3}-58 b^{4}+160 b^{5}+50 b^{6}-16 b^{7}-5 b^{8}\right)(a-c-\bar{w})^{2}}{64(1+b)^{2}(2+b)^{2}\left(2+2 b-b^{2}\right)^{2}}>0,
\end{aligned}
$$

which is the case for $b<0.51537$. Thus, contrary to what has been the case so far, FDI may indeed be a better option for the policy maker than cross-border merger, but only if $b$ is high. The reason is that FDI yields higher total output than a cross-border merger, implying a larger consumer surplus in the former case. However, for sufficiently low values of $b$ this is counteracted by the fact that union utility is higher in the cross-border case. When $b$ approaches unity, wages in firm 1 approach the foreign level, and the output effect obviously dominates the wage/utility effect.

What remains to be shown is the welfare ranking between domestic merger and oligopoly. As before, this depends on merger synergies. For $\sigma=0$, oligopoly is always preferred:

$$
W^{D}-\left.W^{O}\right|_{\sigma=0}=-\frac{b\left(40+70 b-10 b^{2}-33 b^{3}+10 b^{4}\right)(a-c-\bar{w})^{2}}{64\left(2+2 b-b^{2}\right)^{2}(1+b)^{2}}<0 .
$$


It is also possible to show that for $\sigma=\sigma_{C D}:=\frac{a-c-\bar{w}}{c} S_{C D}$, domestic merger always welfare dominates oligopoly. Let $\sigma^{*}$ denote the level of merger synergies that makes the policy maker indifferent between $M_{D}$ and $M_{O} \cdot{ }^{29}$ Notice that (as before) $\sigma_{D O}:=\frac{a-c-\bar{w}}{c} S_{D O}<\sigma^{*}$ since

$$
W_{D}-\left.W_{O}\right|_{\sigma=\sigma_{D O}}=\frac{b(a-c-\bar{w})^{2}\left(7 b^{2}-18 b+4 \sqrt{(1+b)^{3}}\right)}{64(1+b)^{3}}<0 .
$$

Proposition 11. Given that $\varphi>\varphi_{F C}$, the scope for domestic merger policies when consumer welfare is taken into account according to (14), is the following:

(i) Merger policy is redundant for $\sigma>\sigma_{C D}$.

(ii) A national champion policy is effective and optimal if (I) $\varphi>\varphi_{F D}$ and $\sigma \in$ $\left(\sigma^{*}, \sigma_{C D}\right)$ and if (II) $\sigma<\sigma^{*}, \varphi>\varphi_{F D}$ and $\varphi<\varphi_{F O}$.

(iii) A ban on all mergers is effective and optimal if (I) $\sigma<\sigma^{*}$ and $\varphi>\varphi_{F O}$ and if (II) $\varphi<\varphi_{F D}, \varphi<\varphi_{F O}$ and $b>0.51537$.

(iv) National champion policies or a ban on all mergers are ineffective and counterproductive for $\varphi<\varphi_{F D}, \varphi<\varphi_{F O}$ and $b<0.51537$.

Proof. The proof is equivalent to that of Proposition 8. The only new case is that a ban on mergers is effective and optimal for $\varphi<\varphi_{F D}, \varphi<\varphi_{F O}$ and $b>0.51537$. This is the situation where FDI is chosen over both oligopoly and domestic merger by the decisive owners and FDI is preferred by the policy maker to a cross-border merger, as discussed above. Q.E.D.

Qualitatively, these results are much the same as before. The key difference is that, when consumer welfare is taken into account, FDI might be a better option than a cross-border

\footnotetext{
${ }^{29}$ This is a rather detailed expression, not reported here. It is, however, not necessary, as long as we can show that $\sigma^{*} \in\left(\sigma_{D O}, \sigma_{C D}\right)$.
} 
merger from a welfare point of view. This changes the optimal policy when FDI costs are low and $b$ is high.

\subsection{More decentralised wage setting}

Clearly, industry-wide unions are not the only relevant trade union structure. In some countries (e.g., the US) wage setting takes place at a more decentralised level. In principle, there are two other possibilities: trade unions can either be firm-specific or plant-specific. In the former case, unions are organised according to the (domestic) boundaries of the firm. With two domestic firms there will be two domestic unions, but a domestic merger implies that the two firm-specific unions also merge and cover all workers in the new domestically merged firm. On the other hand, if the unions are plant-specific, a domestic merger does not imply that the two unions merge. Instead, they remain as two independent unions covering the workers in each of the two plants, respectively, of the merged firm. Without going through a formal analysis, we can use the insights from Lommerud, Straume and Sørgard (2005) - who analyse wage effects of corporate mergers when unions can be either firm-specific or plantspecific - to discuss how the main mechanisms of our model will change under these two alternative assumptions on the trade union structure.

Whether unions are plant-specific or firm-specific, wages will be lower in the benchmark oligopoly equilibrium, compared with the case of industry-wide unions. ${ }^{30}$ This means that incentives for cross-border merger or FDI are reduced. However, the effects of a domestic merger depend crucially on whether wages are set at the firm level or the plant level. If unions

\footnotetext{
${ }^{30}$ The distinction between firm-specific and plant-specific unions is of course only relevant in case of a merger. In the benchmark oligopoly, the equilibrium is identical under the two different union structures.
} 
are firm-specific, a domestic merger will lead to a wage increase for the merged firm even in the absence of merger synergies (i.e., for $\sigma=0$ ). The reason is that the corporate merger eliminates competition between the two firm-specific unions. Obviously, this wage increase will be reinforced if $\sigma>0$. Thus, the domestic merger alternative becomes less attractive for the firms compared with all other alternatives. On the other hand, the domestic merger alternative becomes more attractive for the policy maker, since workers benefit more from the merger if they are organised in firm-specific unions. Thus, under firm-specific unions, the discrepancy between private and social merger incentives is larger. Since the FDI option is less attractive compared with the benchmark oligopoly, the policy maker can to a larger extent block the cross-border option without causing capital flight through FDI. On the other hand, though, it is less likely that this policy will induce the most desired option: a domestic merger.

If unions are plant-specific, the wage effects of a domestic merger are very different. A domestic merger will now lead to lower wages through increased inter-union competition. This means that the wage effects of a domestic merger mirror those of a cross-border one. Compared with the case of industry-wide or firm-specific unions, this will clearly increase corporate incentives for domestic merger (and correspondingly reduce incentives for crossborder merger). Consequently, the scope for a "national champion" policy will be significantly reduced. On the other hand, the erosion of union rents due to a domestic merger will make the domestic merger alternative less attractive, compared with the benchmark oligopoly, making it more likely that the optimal merger policy is to ban all mergers.

\section{Concluding Remarks}

The ongoing process of investment liberalisation has made international mergers much more commonplace than they were just some few years ago. The purpose of this paper has been to discuss if national champion type merger policies can be made sense of in a rather standard 
model of international unionised oligopoly. We have chosen assumptions that consistently seem to favour a national champion argument: international mergers depress unionised wages; domestic mergers entail larger non-wage variable cost synergies than do international ones; policy makers care more for domestic workers than for domestically residing capital owners. This approach, of course, makes more sense if one wants to argue that even in such a benign environment national champion policies can seriously backfire.

We first investigate a model where a given domestic firm only has three options: to merge cross-border, to merge domestically, or not to engage in a merger. Then a national champion policy can make sense, in particular when the cost synergies associated with domestic merger are large enough. (However, if these cost savings are very large, national champion policy becomes redundant, since the outcome would be domestic merger even in the absence of policy.)

The chief innovation of the paper is to introduce a fourth alternative for the given domestic firm, namely to move all production to a non-unionised location -- but then also carrying a presumably large fixed cost of relocation. ${ }^{31}$ This drastically reduces the scope for a ban on international mergers. For many parameter constellations a national champion policy will be what we dub "ineffective and counterproductive". This means that blocking an international merger will not produce the desired alternative, namely a domestic merger. Instead this will provoke an outcome that is even worse for the policy maker, namely capital flight.

However the scope for economic patriotism in merger policy is only reduced, not eliminated by the introduction of the capital flight option. Three key parameters in the model are the size of

\footnotetext{
${ }^{31}$ Much research has studied either the choice between domestic or cross-border merger, or the choice between cross-border merger and greenfield FDI, but it seems obvious that all these options should ideally be studied simultaneously. The current paper is a first step in this direction.
} 
the domestic merger synergies, the degree of product differentiation among the products of the oligopolists and the fixed relocation cost. Generally speaking, intermediate domestic nonlabour cost synergies and a low degree of product differentiation can save the national champion argument. The same applies for a high fixed cost of greenfield investment, which to some extent only amounts to blocking the relocation option. We know of no systematic investigation of when and where economic patriotism seemingly has influenced merger decisions, but we have an impression that several well-known examples (as most of those mentioned in the introduction) concerns infrastructure industries, where relocation of production can be extremely expensive - and where products often are little differentiated.

The fact that the analysis of this paper seems to warn that national champion policies may be futile does not mean that international mergers are beneficial. Within the model, international mergers can be harmful because they hurt the position of unionised workers without realising the non-labour costs savings that a domestic merger would offer (by assumption). One can easily understand that policy makers would worry about this, but national champion merger policy is the correct solution only in special circumstances.

It is hard to come up with an alternative, realistic policy option that would put things right. The model presents a picture of "ordinary workers" in affluent countries that owe their good fortune first to the fact that the firms they work in have some market power, and second to the fact that these workers in turn manage to capture some of the profit created by this market power. In a globalising world where both trade and investments are liberalised it will probably be difficult to base a country's prosperity on market power in some sense. In particular, it will probably become increasingly hard to cage capital in so that organised labour can secure their share of the spoils. This is exactly what this paper is about: banning crossborder mergers is an attempt to lock capital to one particular economy, but this does not work unless one can cage capital in completely by also banning the physical relocation of 
investments. Perhaps policy makers should realise this, and that the essential point to keep a country prosperous in the longer term is to make sure that the inhabitants of that country are so highly productive that high wages can be sustained also in the absence of any market power.

\section{Appendix A}

Below we report explicit expressions for equilibrium production, wages, profits and union rents and welfare in the different market structures. Notice that $W^{k}$ is defined as $U^{k}+$ $\frac{1}{2}(C S)^{k}$ as explained in Section 5.2. Notice also that $W^{D}$ is only reported in reduced form, since the detailed expression is rather lengthy.

Benchmark oligopoly $\left(M_{O}\right)$ :

$$
\begin{gathered}
q_{1}^{O}=q_{2}^{O}=\frac{a-c-\bar{w}}{4(1+b)} \\
q_{3}^{O}=\frac{(2+b)(a-c-\bar{w})}{4(1+b)} \\
w_{1}^{O}=w_{2}^{O}=\frac{(2-b)(a-c)+(2+b) \bar{w}}{4} \\
\pi_{1}^{O}=\pi_{2}^{O}=\frac{(a-c-\bar{w})^{2}}{16(1+b)^{2}} \\
W_{3}^{O}=\frac{(2+b)^{2}(a-c-\bar{w})^{2}}{16(1+b)^{2}} \\
U^{O}=\frac{(2-b)(a-c-\bar{w})^{2}}{8(1+b)} \\
64(1+b)^{2}
\end{gathered}
$$


Domestic merger $\left(M_{D}\right)$ :

$$
\begin{gathered}
q_{1}^{D}=q_{2}^{D}=\frac{(2-b)(a-c-\bar{w})+2 c \sigma}{4\left(2-b^{2}+2 b\right)} \\
q_{3}^{D}=\frac{\left(4+2 b-b^{2}\right)(a-c-\bar{w})-2 c \sigma b}{4\left(2-b^{2}+2 b\right)} \\
w_{1}^{D}=w_{2}^{D}=\frac{(2-b)(a-c)+(2+b) \bar{w}+2 c \sigma}{4} \\
\pi_{1}^{D}=\pi_{2}^{D}=\left(\frac{1+b}{16}\right)\left(\frac{(2-b)(a-c-\bar{w})+2 c \sigma}{2-b^{2}+2 b}\right)^{2} \\
\pi_{3}^{D}=\frac{\left(\left(4+2 b-b^{2}\right)(a-c-\bar{w})-2 c \sigma b\right)^{2}}{16\left(2-b^{2}+2 b\right)^{2}} \\
U^{D}=\frac{((2-b)(a-c-\bar{w})+2 c \sigma)^{2}}{8\left(2-b^{2}+2 b\right)} \\
W^{D}=U^{D}+\frac{1}{2}\left(\frac{1}{2} \sum_{i=1}^{3}\left(q_{i}^{D}\right)^{2}+b\left(q_{1}^{D} q_{2}^{D}+q_{1}^{D} q_{3}^{D}+q_{2}^{D} q_{3}^{D}\right)\right)
\end{gathered}
$$

Cross-border merger $\left(M_{C}\right)$ :

$$
\begin{gathered}
q_{1}^{C}=\frac{(2-b)(a-c-\bar{w})}{4\left(2-b^{2}+2 b\right)} \\
q_{2}^{C}=\frac{(a-c-\bar{w})}{2\left(2-b^{2}+2 b\right)} \\
q_{3}^{C}=\frac{\left(4-b^{2}+b\right)(a-c-\bar{w})}{4\left(2-b^{2}+2 b\right)} \\
w_{1}^{C}=\frac{(1-b)(a-c)+(1+b) \bar{w}}{2}
\end{gathered}
$$




$$
\begin{gathered}
w_{2}^{C}=\frac{(2-b)(a-c)+(2+b) \bar{w}}{4} \\
\pi_{1}^{C}+\pi_{3}^{C}=\frac{\left(20+20 b-10 b^{2}-8 b^{3}+3 b^{4}\right)(a-c-\bar{w})^{2}}{16\left(2-b^{2}+2 b\right)^{2}} \\
\pi_{2}^{C}=\frac{(a-c-\bar{w})^{2}}{4\left(2-b^{2}+2 b\right)^{2}} \\
U^{C}=\frac{((2-b)(a-c-\bar{w}))^{2}}{8\left(2-b^{2}+2 b\right)} \\
W^{C}=\frac{\left(88+44 b-90 b^{2}+36 b^{3}-5 b^{4}\right)(a-c-\bar{w})^{2}}{64\left(2-b^{2}+2 b\right)}
\end{gathered}
$$

Capital flight $\left(M_{F}\right)$ :

$$
\begin{gathered}
q_{1}^{F}=q_{3}^{F}=\frac{(4+3 b)(a-c-\bar{w})}{4(1+b)(2+b)} \\
q_{2}^{F}=\frac{a-c-\bar{w}}{4(1+b)} \\
w_{2}^{F}=\frac{(2-b)(a-c)+(2+3 b) \bar{w}}{2(2+b)} \\
\pi_{1}^{F}=\pi_{3}^{F}-f=\frac{(4+3 b)^{2}(a-c-\bar{w})^{2}}{16(1+b)^{2}(2+b)^{2}}-f \\
\pi_{2}^{F}=\frac{(a-c-\bar{w})^{2}}{16(1+b)^{2}} \\
W^{F}=\frac{\left(68+148 b-99 b^{2}+22 b^{3}\right)(a-c-\bar{w})^{2}}{64(1+b)^{2}(2+b)^{2}} \\
U^{F}=\frac{(2-b)(a-c-\bar{w})^{2}}{8(1+b)(2+b)} \\
(14 b)
\end{gathered}
$$


Cross-border merger under wage solidarity $\left(M_{C e}\right)$ :

$$
\begin{aligned}
& q_{1}^{C e}=\left\{\begin{array}{ccc}
\frac{\left(16-20 b-2 b^{2}+3 b^{3}\right)(a-c-\bar{w})}{4\left(2-b^{2}+2 b\right)\left(8-4 b-b^{2}\right)} & \text { if } & b<0.69459 \\
0 & \text { if } & b>0.69459
\end{array}\right. \\
& q_{2}^{C e}=\left\{\begin{array}{ccc}
\frac{(2-b)\left(4+b+b^{2}\right)(a-c-\bar{w})}{2\left(2-b^{2}+2 b\right)\left(8-4 b-b^{2}\right)} & \text { if } & b<0.69459 \\
\frac{a-c-\bar{w}}{2(2+b)} & \text { if } & b>0.69459
\end{array}\right. \\
& q_{3}^{C e}=\left\{\begin{array}{clc}
\frac{(2-b)\left(16+4 b-5 b^{2}\right)(a-c-\bar{w})}{4\left(2-b^{2}+2 b\right)\left(8-4 b-b^{2}\right)} & \text { if } & b<0.69459 \\
\frac{(4+b)(a-c-\bar{w})}{4(2+b)} & \text { if } \quad b>0.69459
\end{array}\right. \\
& w_{1}^{C e}=w_{2}^{C e}=\left\{\begin{array}{clc}
\frac{(1-b)(4-b)(a-c)+\bar{w}\left(4+b-2 b^{2}\right)}{12-(2+b)^{2}} & \text { if } \quad b<0.69459 \\
\frac{(2-b)(a-c)+\bar{w}(2+b)}{4} & \text { if } \quad b>0.69459
\end{array}\right. \\
& \pi_{1}^{C e}+\pi_{3}^{C e}=\left\{\begin{array}{cl}
\frac{\beta(a-c-\bar{w})^{2}}{8\left(2+2 b-b^{2}\right)^{2}\left(8-4 b-b^{2}\right)^{2}} & \text { if } \quad b<0.69459 \\
\frac{(4+b)^{2}(a-c-\bar{w})^{2}}{16(2+b)^{2}} & \text { if } \quad b>0.69459
\end{array}\right. \\
& \beta=640-64 b-1016 b^{2}+232 b^{3}+472 b^{4}-172 b^{5}-35 b^{6}+15 b^{7}>0 \\
& \pi_{2}^{C e}=\left\{\begin{array}{ccc}
\frac{(2-b)^{2}\left(4+b+b^{2}\right)^{2}(a-c-\bar{w})^{2}}{4\left(2+2 b-b^{2}\right)^{2}\left(8-4 b-b^{2}\right)^{2}} & \text { if } & b<0.69459 \\
\frac{(a-c-\bar{w})^{2}}{4(2+b)^{2}} & \text { if } \quad b>0.69459
\end{array}\right. \\
& U^{C e}=\left\{\begin{array}{ccc}
\frac{(1-b)(4-b)^{2}(a-c-\bar{w})^{2}}{4\left(2+2 b-b^{2}\right)\left(8-4 b-b^{2}\right)} & \text { if } \quad b<0.69459 \\
\frac{(2-b)(a-c-\bar{w})^{2}}{8(2+b)} & \text { if } \quad b>0.69459
\end{array}\right.
\end{aligned}
$$


For the derivation of the equilibrium outcome in $M_{C e}$, notice that the union chooses between two strategies; setting the uniform wage sufficiently low to induce production in firm 1, or high, inducing the multinational firm to close down domestic production. At $b=0.69459$ the union is indifferent between these two strategies. For higher values of $b$, the wage necessary to keep production in firm 1 is so low that the union switches to a high wage. This wage is of course set in an optimal way given that firm 1 is closed down.

\section{Appendix B}

In this appendix we show that $\varphi_{F D}$ is decreasing in $b$ when $S<S_{C D}$.

First,

$$
\gamma:=\frac{\partial \varphi_{F D}}{\partial b}=\frac{-A+4(2+b)^{3}(1+b)^{3}\left(\left(6-2 b-3 b^{2}+2 b^{3}\right) S+S^{2}\left(2-2 b-3 b^{2}\right)\right)}{8(2+b)^{3}(1+b)^{3}\left(2+2 b-b^{2}\right)^{3}}
$$

where $A:=128+720 b+1344 b^{2}+760 b^{3}-456 b^{4}-594 b^{5}-40 b^{6}+119 b^{7}+21 b^{8}-$ $5 b^{9}+b^{10}$.

Notice that

1. For $2-2 b-3 b^{2}<0$, i.e., $b>\frac{\sqrt{7}-1}{3}, \gamma$ is increasing in $S$ for $S<S_{1}:=\frac{2 b^{3}-3 b^{2}-2 b+6}{-2+2 b+3 b^{2}}$ and decreasing in $S$ thereafter. Thus, $\gamma \leq \gamma\left(S_{1}\right)$.

2. For $2-2 b-3 b^{2}<0$, i.e., $b<\frac{\sqrt{7}-1}{3}, \gamma$ is increasing in $S$. If $S<S_{C D}, \gamma<\gamma\left(S_{C D}\right)$. However, since it is possible to show that $S_{1}>S_{C D}$ in the specified region, we also have $\gamma<\gamma\left(S_{1}\right)$.

Since

$$
\gamma\left(S_{1}\right)=-\frac{A}{8(2+b)^{3}(1+b)^{3}\left(2+2 b-b^{2}\right)^{3}}<0,
$$


we know that $\gamma<0$ given $S<S_{C D}$.

\section{Acknowledgements}

We thank three anonymous referees for very valuable comments and suggestions.

\section{References}

Almeida, R. (2007). The labor market effects of foreign owned firms. Journal of International Economics, 72, 75-96.

Barros, P.P., \& Cabral, L. (1994). Merger policy in open economies. European Economic Review 38, 1041-1055.

Bjorvatn, K. (2004). Economic intergration and the profitability of cross-border acquisitions. European Economic Review 48, 1211-1226.

Blanchard, O.J., \& Giavazzi, F. (2003). Macroeconomic effects of regulation and deregulation in goods and labor markets. Quarterly Journal of Economics 118, 879-907.

Brown, C., \& Medoff, J.L. (1988). The impact of firm acquisition on labour. In: A. Auerbach (Ed.), Corporate takeovers: Causes and consequences. Chicago: University of Chicago Press.

Calmette, M.-F. (2008). The effects of trade liberalization between heterogeneous countries on endogenous mergers. Review of International Economics 16, 874-892.

Cremieux, P.-Y. \& Van Audenrode, M. (1996). Mergers and bargaining in the airline industry. Labour 10, 297-318. 
Deneckere, R., \& Davidson, C. (1985). Incentives to form coalitions with Bertrand competition. RAND Journal of Economics 16, 473-486.

Dhillon, A., \& Petrakis, E. (2002). A generalised wage rigidity result. International Journal of Industrial Organization 20, 285-311.

Egger, H., \& Kreickemeier, U. (2008). International fragmentation: Boon or bane for domestic employment? European Economic Review 52, 116-132, 2008.

Girma, S., \& Görg, H. (2007). Evaluating the foreign ownership wage premium using a difference-in-differences matching approach. Journal of International Economics 72, 97-112.

Gokhale, J., Groshen, E., \& Neumark, D. (1995). Do hostile takeovers reduce extramarginal wage payments? Review of Economics and Statistics 77, 470-485.

Grossman, G., Helpman E., \& Szeidl, A. (2006). Optimal integration strategies for multinational firms. Journal of International Economics 70, 216-238.

Gugler, K., \& Yurtoglu, B.B. (2004). The effects of mergers on company employment in the USA and Europe. International Journal of Industrial Organization 22, 481-502.

Haufler, A., \& Nielsen, S.B. (2008). Merger policy to promote 'global players'? A simple model. Oxford Economic Papers 60, 517-545.

Haufler, A., \& Schulte, C. (2007). Merger policy and tax competition. München: CESifo Working Paper No 2157.

Head, K., \& Ries, J. (1997). International mergers and welfare under decentralized competition policy. Canadian Journal of Economics 30, 1104-1123.

Hekmat, A. (1995). The effects of different types of mergers on union and non-union wages in the United States. Journal of Economics 21, 65-69. 
Heyman, F., Sjöholm, F., \& Tingvall, P.G. (2007). Is there really a foreign ownership wage premium? Evidence from matched employer-employee data. Journal of International Economics 73, 355-376.

Horn, H., \& Persson, L. (2001a). The equilibrium ownership of an international oligopoly. Journal of International Economics 53, 307-333.

Horn, H., \& Persson, L. (2001b). Endogenous mergers in concentrated markets. International Journal of Industrial Organization 19, 244-276.

Huck, S., \& Konrad, K.A. (2004). Merger profitability and trade policy. Scandinavian Journal of Economics 106, 107-122, 2004.

Hyytinen, A., Steen, F., \& Toivanen, O. (2010). Cartels uncovered. CEPR Discussion Paper No. 7761.

Lommerud, K.E., Meland, F., \& Straume, O.R. (2009). Can deunionization lead to international outsourcing? Journal of International Economics 77, 109-119.

Lommerud, K.E., Meland, F., \& Sørgard, L. (2003). Unionised oligopoly, trade liberalisation and location choice. Economic Journal 113, 782-801.

Lommerud, K.E., Olsen, T.E., \& Straume, O.R. (2010). Cross-border mergers and strategic trade policy with two-part taxation: is international policy coordination beneficial? Journal of Industry, Competition and Trade 10, 161-186.

Lommerud, K.E., Sandvik, B., \& Straume, O.R. (2004). Good jobs, bad jobs and redistribution. Scandinavian Journal of Economics 104, 703-720.

Lommerud, K.E., Straume, O.R., \& Sørgard, L. (2006). National versus international mergers in unionized oligopoly. RAND Journal of Economics 37, 212-233. 
Marginson, P., \& Schulten, T. (1999). The Europeanisation of collective bargaining. EIROnline, July 28, 1999. Available at www.eiro.eurofound.eu.int/1999/07.

McGuckin, R.H., \& Nguyen, S.V. (2001). The impact of ownership changes: A view from the labor markets. International Journal of Industrial Organization 19, 739-762.

Meland, F. (2002). Unions and market integration in contests. Public Choice 112, 293-304.

Mukherjee, A., \& Zhao, L. (2009). Unionization structure and the incentives for cross-border merger. Manuscript, University of Nottingham.

Mugele, C., \& Schnitzer, M. (2008). Organization of multinational activities and ownership structure. International Journal of Industrial Organization 26, 1274-1289.

Naylor, R.A. (1998). International trade and economic integration when labour markets are generally unionised. European Economic Review 42, 1251-1267.

Neary, J.P. (2002). Foreign competition and wage inequality. Review of International Economics $10,680-693$.

Neary, J.P. (2007). Cross-border mergers as instruments of comparative advantage. Review of Economic Studies 74, 1229-1257.

Neary, J.P. (2009). Trade costs and foreign direct investment. International Review of Economics and Finance 18, 207-218.

Nocke, V., \& Yeaple, S. (2007). Cross-border mergers and acquisitions vs. greenfield foreign direct investment: The role of firm heterogeneity. Journal of International Economics 72, 336365.

Norbäck, P.-J., \& Persson, L. (2007). Investment liberalization - Why a restrictive cross-border merger policy may be counterproductive. Journal of International Economics 72, 366-380. 
NTB (Norsk telegrambyrå) (2008). Kristin i Davos: - USA er i "deep shit". [Kristin in Davos: - USA is in "deep shit".] 24.01.2008.

Peoples, J., Hekmat, A., \& Moini, A.H. (1993). Corporate mergers and union wage premiums. Journal of Economics and Finance 17, 65-75.

Raff, H., Ryan, M., \& Stähler, F. (2009). The Choice of Market Entry Mode: Greenfield Investment, $\mathrm{M}$ and $\mathrm{A}$ and Joint Venture. International Review of Economics and Finance 18, 310.

Saint-Paul, G. (2007). Making sense of Bolkestein-bashing: trade liberalization under segmented labour markets. Journal of International Economics 73, 152-174.

Salant, S.W., Switzer, S., \& Reynolds, R.N. (1983). Losses from horizontal merger: The effects of an exogenous change in industry structure on Cournot-Nash equilibrium. Quarterly Journal of Economics 98, 185-199.

Straume, O.R. (2003). International mergers and trade liberalisation: implications for unionised labour. International Journal of Industrial Organization 21, 717-735.

Südekum, J. (2008). Cross-border mergers and national champions in an integrating economy. Journal of Institutional and Theoretical Economics 164, 477-508.

Südekum, J. (2009). National champions and globalization. Canadian Journal of Economics 43, 204-231.

UNCTAD (2005). World Investment Report.

Wälde, K. \& Weiss, P. (2007). International competition, downsizing and wage inequality. Journal of International Economics 73, 396-406. 